\title{
THE RELATIONS BETWEEN THE REPUBLIC OF POLAND AND THE DEMOCRATIC PEOPLE'S REPUBLIC OF KOREA. THE HISTORICAL ANALYSIS
}

\author{
Marceli Burdelski
}

The sixtieth anniversary of entering into diplomatic relations between Republic of Poland and Democratic People's Republic of Korea inclines to draw up a balance sheet. Korea is located far away from Poland, in a very different civilization circle, the neo-Confucian one. It has 5 thousand years of history; the legendary Tangun in a year 2333 B.C. has founded the first Korean state Kodzoson. The history is generally difficult, numerous invasions of grand neighbors (China, Japan). The Korean chronicle compared Korea to a prawn swimming in between of two whales. Such difficult history is also the attribute of Poland. Poland was also a subject of partitions, numerous invasions of the neighbors. Polish and Koreans have common national features: pride, inexorability and independence.

Korea was victim of Japanese colonialism and has not restored its independence after the end of World War II. The future of Korea was decided by the leaders of United States and Soviet Union. Two military occupation zones have been created. The attempt to build a unified government ad interim and parliament has failed among growing Cold War tensions. The actions undertaken by the UN - not recognized by the Soviet Union - have also fallen short. So in different environments two separate Korean States have been founded: People's Democratic Republic of Korea 
and Republic of Korea that pretended from the beginning to represent the whole Korea.

The general purpose of article is show the Evolution of Poland's North Korea's relations in past six decades. Article consist of three part. First present of Cold War period and situations Poland's diplomacy in conditions' of dependency from Soviet Union. Second presents polish contribution to Neutral Countries Supervisory Commission to Korea. Third presents polish and northkorean relations after Cold War. Poland transformed in last twenty years in politics, economic, social system and priorities of foreign policy. The changes of political and social system in North Korea was minimal.

\section{THE COLD WAR ERA}

On 8.10.1948 the government of DPRK has announced the foundation of Democratic People's Republic of Korea and proposed Poland to establish diplomatic relations between those two states. ${ }^{1}$ In a response the government of Republic of Poland on has recognized the DPRK and accepted the proposal. On 7.06.1950 r. both governments have signed the agreement of exchange of diplomatic representatives in a rank of ambassadors. Poland was the third state that has recognized the DPRK. The symbolic fact is that cars of Polish embassy do have the number 3 on their license plates. At the beginning of the fifties was created Polish Embassy in the DPRK. The embassy was initially working during the difficult years of the Korean War.

The first diplomatic representative of Republic of Poland (R.P.) was chargé d'affaires Stanisław Dodin, who started his mission on $9^{\text {th }}$ July 1948. The first ambassador in the DPRK was Juliusz Burgin accredited to the government of PRC in Beijing.

The mission of ambassador of PRL (Polska Rzeczpospolita Ludowa -Peoples' Republic of Poland) in the DPRK during fifties, sixties, seventies

\footnotetext{
1 Stosunki dyplomatyczne Polski Ministerstwo Spraw Zagranicznych 1944-1982 r. Informator, tom IV, Ministerstwo Spraw Zagranicznych, Warszawa 1984, p. 129.
} 
and eighties was performed by: Stanisław Kiryluk 1952-1954, Jędrzej Siedlecki1954-1959, only in Pyongyang, Józef Dryglas, 1959-1964, Władysław Napieraj, 1964-1968, Józef Dryglas, 1968-1971, Tadeusz Białkowski, 1971-1978, Jerzy Pękala, 1978-1981, Leon Tomaszewski, 1981-1985, and Mieczysław Dedo 1985.

From the DPRK side the mission of Ambassador in Poland during the period mentioned above was fulfilled by: Choy Ir, 1951-1953, Choe Bin, 1953-1954, Ho Gook Bon, 1954-1958, Kim Haek In, 1959-1962, Li Dok Hion, 1962-1968, Kweung Bong Ryong, 1968-1970, Kim Hi Soun, 1970-1973, Paek Naim Sun, 1974-1979 (later DPRK's foreign minister) and O Uung Kweun, from $6^{\text {th }}$ April 1979.

The relations between Poland and DPRK were very close during the fifties and sixties. It resulted from fellowship of political systems and membership to the same ideological-political alliance. Poland supported DPRK during the Korean War, providing aid with goods shipments and military equipment as well. Poland was inviting children, orphans of the victims of the Korean War. Those children, around 200, have been placed to the orphanage, first in Golotczyzna, later on in the Swider near Otwock.

By virtue of the Korean War Armistice Agreement from 27th July 1953, the DPRK and Chinese People's Volunteer Army (PVA) has invited Poland to join Neutral Nations Supervisory Commission (NNSC) to carry out the functions of armistice supervision, observation, inspection, and investigation. Polish activity within the NNSC is described in further parts of the text. ${ }^{2}$

During the years from establishing diplomatic ties until 1989 the intensive political dialogue between Poland and the DPRK was taking place. On 2-6 July 1956 Poland hosted high level North Korean delegation with the Chairman of Cabinet and the Chairman of Central Committee of the Korean Workers' Party, Marshal Kim IL Sung. The delegation was received

\footnotetext{
2 Ch. Birchmeier, M. Burdelski, E. Jendraszczak, 50-lecie Komisji Nadzorczej Państw Neutralnych $w$ Korei, Warszawa 2003, p. 441.
} 
by Polish Prime Minister Józef Cyrankiewicz. After completing the talks the joint statement was issued. The visit in Poland was part of large 50-days visit to Soviet Union and European socialist states. The main purpose of the visit was acquiring of material aid for post war reconstruction of the DPRK. Kim Il Sung has visited Orphanage in Swider inter alia.

Next year, the reciprocal visit of Polish government delegation to DPRK has been made. Prime Minister Józef Cyrankiewicz and Kim Il Sung have signed the joint statement and intergovernmental agreement on scientifictechnical cooperation. On 1959 the Chairman of Poland's State's Council Aleksander Zawadzki has visited the DPRK.

The exchange of parliamentary delegations of highest rank has been made in 1956 when the Speaker of Highest Peoples' Assembly of the DPRK Kim Too Bong was taking a visit to Poland. On 1959 his successor Choy En Hen, and on 1969, Li Jon Ho made similar visits.

There was also exchange between the foreign ministries of two states. There were mutual ministerial visits as well. Poland has supported numerous times the North Korean initiatives aiming at unification of Korea. Many agreements on regulating mutual cooperation have been signed.

During the course of the sixties the relations have become more lukewarm. The Soviet-Chinese conflict had to impact the Polish relations with the DPRK, which position was neutral during this standoff, however more affiliated with China.

On 1953 to the village of Płaskowice near Lwówek Sląski have come 1270 children. Until year 1959, in Poland have lived 6000 Korean orphans. They have gained education in Poland and learned Polish language. After coming back to North Korea many of them have joined diplomatic service e.g.: Pak Dong Ho, Han Ul Pyo, Choe Sen Mu (current director of Polish language chair at Pyongyang University of Foreign Languages, colonel Han Kyon Sik).

Poland has also received over 500 students from DPRK. They mainly studied on technical and agriculture universities. During the 1955-56 period, out of 575 foreign students in Poland 365 were from North Korea. This number has decreased significantly during the sixties period. During the academic year 1960/61 among 740 foreign students only 108 were 
from DPRK. During the year 1965/66 there was not even single student from North Korea ${ }^{3}$.

Through the fifties the trade exchange had been increasing. On $28^{\text {th }}$ July 1953 the presidium of Polish Cabinet has passed the resolution to provide the DPRK with aid to rebuild its economy. In 1955 Poland assisted in constructing the hospital in Hamhung. Up to this day it is called a "Polish Hospital". At the beginning Polish medical personnel has worked over there. Currently under preparation is the project to help the hospital. The project is led by Polska Akcja Humanitarna (Polish Humanitarian Aid), supervised by Janina Ochojska.

The project will be realized from the funds of organization ECHO of European Union. Polish specialists have participated in the reconstruction and expansion of coal mines, including the mine in Andju. Poles have also rebuilt the rolling-stock manufacturing and repair plant.

The funding of Chopol Company was the sign of cooperation in the maritime transportation. On $19^{\text {th }}$ December 1965 , by virtue of agreement between the governments of Poland and DPRK, the Korean-Polish Company of Maritime Brokers has been created. The agreement was signed for 4 years. After this period it was automatically prolonged. The headquarters of Chopol is based in Pyongyang and the branch is in Gdynia.

During the eighties there was a warming up in the relation between Pyongyang and Warsaw. There was visit's exchange at highest official level. On 27-29 May 1984 Kim Il Sung has made the official visit to Poland as response for the invitation issued by general Wojciech Jaruzelski. The DPRK sympathized then with the political line of Polish communist party against the Solidarity movement. Poland has supported the efforts of DPRK aiming at peaceful reunification of Korea. On September 1986 the reciprocal visit to Pyongyang has been made by Wojciech Jaruzelski. During the visit the development of economic cooperation and trade exchange was agreed.

The last chord of Polish presence in the DPRK before changing the political system was participation of large Polish delegation at World's

\footnotetext{
3 Sprawa studentów koreańskich w Polsce. Archive Ministry Foreign affairs The Peoples Republic of Poland, Manuscript, p. 11
} 
Youth and Students in Pyongyang. The head of the delegation were Aleksander Kwaśniewski, Leszek Miler, and Jerzy Szmajdziński. The headquarters of Polish delegation was in Nampho at "Zawisza Czarny" yacht.

The political changes in Poland have impacted on the status of relations with the DPRK. The Korea has reacted in a very negative manner to the diplomatic recognition of Republic of Korea by Poland and the development of ties with this state. DPRK's students in Poland had to terminate their stay.

\section{MISSION OF POLAND WITHIN THE NEUTRAL NATIONS SUPERVISORY COMMISSION (NNSC)}

Recent participation of Polish Army in the stabilization and reconstruction of Iraq is a reason for some satisfaction for Polish society. Very few people remember that international debut of Polish soldiers in the peacekeeping missions has occurred after the end of Korean War. On $27^{\text {th }}$ July 1953 the Armistice Agreement on Korean Peninsula has been signed. The aim of the agreement was to cease the bloodshed in Korea and establish the armistice guarantying the complete cessation of hostilities and all acts of armed force in Korea until a final peaceful settlement could be achieved. Despite the fact of signing the Armistice Agreement on Korean Peninsula, the confrontation of two enemy armies standing against each other, lasts already fifty years. The Supreme Command of Korean People's Army in Panmunjom recently has declared officially that Armistice Agreement is void and the United Nations Command and NNSC do not exist anymore.

The agreement declared the complete cessation of all hostilities in Korea by all armed forces at 22 hours on 27 July 1953 and established so called Military Demarcation Line approximately along the $38^{\text {th }}$ parallel. At the same time the agreement obliged armed forces to withdraw two kilometers from this line so as to establish a Demilitarized Zone (DMZ) between the opposing forces to be $4 \mathrm{~km}$ wide. Furthermore in its provisions the Agreement has regulated some other requirements e.g.: withdrawing all of their 
military forces from the DMZ and from the rear and the coastal islands and waters of Korea of the other side, conditions of rotation of military units and personnel, combat aircraft, armored vehicles, weapons, and ammunition.

To supervision and control of the implementation of the Armistice Agreement several institutions have been established, the most important role among them play Military Armistice Commission (MAC) and Neutral Nations Supervisory Commission (NNSC). The headquarters of those supervisory bodies by virtue of the agreement are located in the small village of Panmunjom placed exactly at the line of cease fire along which the area was delimited called the Joint Security Area (JSA).

The general mission of the Military Armistice Commission shall be to supervise the implementation of the Armistice Agreement and to settle through negotiations any violations of the Armistice Agreement. The MAC as main supervisory and control body of provisions of Armistice Agreement shall settle through negotiations any violations of the Armistice Agreement, and at the same time act as intermediary in transmitting communications between the Commanders of the opposing sides. The Military Armistice commission is composed of ten senior officers, five of whom shall be appointed by the Commander-in-Chief, United Nations Command, and five of whom shall be appointed jointly by the Supreme Commander of the Korean People's Army and the Commander of the Chinese People's Volunteers.

The Neutral Nations Supervisory Commission (NNSC) by virtue of the Agreement provisions carries out the functions of supervision, observation, inspection, and investigation. The NNSC reports the results of such supervision, observation, inspection, and investigation to the Military Armistice Commission.

The NNSC was composed of four senior officers, two of whom shall be appointed by neutral nations nominated by the Commander- in-Chief, United Nations Command, namely, SWEDEN and SWITZERLAND, and two of whom were appointed by neutral nations nominated jointly by the Supreme Commander of the Korean People's Army and the Commander of the Chinese People's Volunteers, namely, POLAND and CZECHOSLOVAKIA. 
By virtue of the Agreement provisions, the NNSC performed its duties through work and assistance of the twenty Neutral Nations Inspection Teams (NNIT). Neutral Nations Inspection Teams were to be stationed at the so called Ports of Entry, 5 in the north and 5 in the south part of Korea. Trough the Ports of Entry the rotation of military units and personnel and combat hardware were allowed. The number of 20 NNIT-s was established as the initial figure, this number might be reduced by agreement of the senior members of both sides on the Military Armistice Commission. Each Neutral Nations Inspection Team was composed of not less than four officers, half of whom shall be from the neutral nations nominated by the Commander-in-Chief, United Nations Command, and half of whom were from the neutral nations nominated jointly by the Supreme Commander of the Korean People's Army, and the Commander of the Chinese People's Volunteers.

At the end of June 1953 the reconnaissance group of around 30 persons has been sent to Beijing. Gen. Mieczysław Wągrowski, designated as a chief of Polish Mission, with other persons has traveled soon to the Far East. The majority of personnel and all of military supplies, transport and communication equipment, medical supply have been moved to Korea in 3 railway transports through the territory of Soviet Union and China. After few weeks Polish team has arrived on-site. The first Polish turn had numbered 301 people, including 42 outside the Ministry of Defense.

The first meeting of NNSC has been conducted $1^{\text {st }}$ on August 1953 in Panmunjom. Poland was represented by gen. M. Wągrowski. The NNSC has initiated its work from preparing and agreeing on statutory documents regulated its activities. Since that moment the NNSC exists under its own flag that is the square divided diagonally into four equal parts (triangles). The triangles in the square are filled with the national colors of the member states. So looking down the flag to the right, the existing triangles have four colors: red, yellow, blue, white.

The locations of camps for personnel of the NNSC have been delimited in close proximity to the place of their official meetings in Panmunjom. On the northern side of Military Demarcation Line have lived the representatives of Poland and Czechoslovakia. Their security was provided by military personnel of Korean People's Army and Chinese People's Volun- 
teers. Similarly on the southern side resided representatives of Switzerland and Sweden. Their security was guaranteed by representatives of the United Nations Command.

The first ten Neutral Nations Inspection Teams (NNIT) started their work in the designated Ports of Entry already on $18^{\text {th }}$ August. Commission has performed its duties initially through the so called Stationary and Mobile NNITs and for special cases - in striking violation - of the Agreement, has created so called Missions of Deputies Members in the NNSC.

Lack of experience, large responsibility and far distance away from the home land was the test for Polish personnel when the situations required decisions needed to be made independently, very fast, but cautiously at the same time.

During the first months, the resolutions of the Commission were passed usually unanimously, further on the larger differences between the members of NNSC have become visible. It has to be noted that the activities of Polish representatives during those distant times were conducted in the environment of vivid ideological confrontation. The authorities of both North and South Korea did not trust the neutrality of NNSC work.

On the south Polish and Czechoslovak officers were alleged of undertaking espionage job. On the north there were allegations against Polish of being too liberal towards cooperating officers from Sweden and Switzerland.

Provocations of southern side were becoming sometimes the form of direct assaults with usage of explosive devices against the NNSC personnel. The northern side has used direct invigilation as a part of so called security and also has kept very strict and literal interpretation of Agreement provisions. In practice it led to the constraints imposed on free movement outside the designated areas and biased estimates of Agreement's obligations observation. On $1^{\text {st }}$ August 1954, the headquarters of Polish Team in the harbor of Pusan was attacked, so it caused the withdrawal from this important port that was the major commodities transit point of South Korea. The whole inspection team of the NNSC was moved to the American military camp, distant several kilometers. That has weakened significantly the effectiveness of control activities of the team. It was the step towards the elimination by 
United Nations Command the activities of stationary NNIT-s in the southern part of Korean peninsula. This action has significantly limited the tasks of NNSC and resulted in reduction of its personnel.

On the day of $7^{\text {th }}$ November, the Polish Mission has suffered tragic casualties. The plane that was given at Commission disposal by Americans has crashed, apart from pilot; major Jakub Zygielski, Captain Władysław Rudnicki and Lieutenant Zygfryd Zieliński have died.

The turns of the personnel of Polish mission in Korea have occurred initially every 9-11 months. From March 1955 manpower of the polish mission was reduced as the scope of practical activities of NNSC. The second turn (1954/1955) numbered already 300 persons, however the next one only 88 , another one just 35 . Since 1960 Polish mission contained 10 persons, and since 1968 only 9 people.

Among well know social-political figures, that were on duty in the Polish Mission can be mentioned: Eugeniusz Wyzner, currently the Deputy of UN General Secretary former foreign minister of Poland; professor Lech Antonowicz, the renown specialist of international public law from UMCS University in Lublin; professor Leszek Kasprzak from Department of Journalism and Political Science of University of Warsaw; professor Stanisław Pawlak, long-term employee of Foreign Ministry of Poland former Polish ambassador to the UN in New York and to Syria and currently adviser of Polish President; Leon Leszek Szkutnik, wellknown linguist and English scholar and then lieutenant, Leonid Teliga, the famous sailor.

Another significant change in the work of Polish mission to the NNSC was caused by the changes in the political landscape after fall of the "Berlin Wall". Dissolution of Czechoslovakia and lack of interests by the government of Czech Republic in taking over previous tasks in the NNSC has initiated the withdrawal of Czech representatives to the NNSC at the northern side of the Military Demarcation Line. According to DPRK's assessment the further existence of NNSC was not needed anymore. Aiming at dissolving the inconvenient NNSC, the DPRK used very effective means to limit abilities of presence and work of Polish representatives. In 1995 as a result of enormous pressure, our delegation with the general Andrzej Owczarek as the head was forced to leave the dislocation area in 
the Northern part of Joint Security Area (JSA) in Panmunjom. Activities of the DPRK have resulted in a serious crisis of mutual relations between Poland and DPRK. Poland has recalled the ambassador from Pyongyang. This has ended the period of Commission activities based on originally agreed principles and its further existence required undertaking some political actions. The decision made in Poland to support the necessity of the existence of NNSC as a link stimulating peace initiatives on the Korean peninsula. Since that moment our representatives in two persons unit, occasionally (3-4 times in a year) take part in the work of NNSC by arriving in Panmunjom from the southern side.

Summarizing over 50 years effort of our country in the work for NNSC, it is must to underscore that over 1000 military and civil personnel have worked in Korea. Those people deserve special thanks and recognition for the efforts made to preserve the peace in the world.

\section{THE POST-COLD WAR ERA}

After systemic change in Poland, the ties between Poland and DPRK have changed. The tensions linked with NNSC were finally resolved in 1996. The consultations at foreign ministries' department level between directors Jerzy Pomianowski and Kim Chong Gook have taken place in Warsaw. Poland has given agreement for Ambassador Park Sang Am. He was ambassador for the very short time. In 1998 Kim Pyong Il, the brother of the Leader Kim Jong Il has become the new ambassador. He performs those duties up to this day. After recalling the ambassador Ryszard Baturo in 1995 Poland has not sent the new ambassador. The new head of the embassy has become Mieczysław Dedo in rank of minister plenipotentiary, the titular ambassador. In 2001 Poland has sent its ambassador to Pyongyang, the nomination received Wojciech Kałuża, his mission has ended in 2005.

On 2005 gen. PhD Roman Iwaszkiewicz the ambassador of Poland to the DPRK was nominated. He is on the mission up to this day. His term and initiatives aimed at the development of mutual relations must be 
evaluated as very successful. His successor will be gen. Edward Pietrzyk. Currently the embassy is led by chargé d'affaires Tomasz Szczepanowski.

Poland maintains periodical political dialogue with the DPRK at the level of foreign vice-ministers and directors of territorial departments. Sporadically occurs the inter-parliamentary exchange. Poland supports full nuclear disarmament of DPRK on the way Six Party Talks process. Poland supports UN Security Council resolutions. Ministry Foreign Affairs Republic of Poland condemns missile test on April and nuclear test made by DPRK in 2009. Poland made Presidency EU Ambassadors in DPRK in 2007 on request Portugal. Portugal haven't Embassy in Pyongyang.

Polish visits to the DPRK:

- The visit of the undersecretary in the Foreign Ministry of Poland Ryszard Sznepf and director of Asia-Pacific Department Tadeusz Chomicki - DPRK, September 2008,

- Political consultation on the level of departments' directors, a visit in Pyongyang of vice-director on April 2008,

- Undersecretary of state Witold Waszczykowski (political consultations) August 2007,

- Undersecretary of state Bogusław Zaleski (political consultations 2004),

- Delegation of parliamentary group Poland-Korea (2002),

- Undersecretary of state Radosław Sikorski (political consultations 2001),

Korean visits to Poland:

- Director of Department of Europe, DPRK's ministry of Foreign Affairs, Kim Chung Gook, political consultations (September 2009),

- Vice-minister of Foreign Affairs of the DPRK Kung Soo Ung (political consultations, May 2008),

- Vice-minister of Foreign Affairs of the DPRK Kung Soo Ung (political consultations, 2005),

- Director of Department of Europe, DPRK's ministry of Foreign Affairs, Kim Chung Gook (DPRK's ministry of Foreign Affairs, 2002), 
- Delegation of parliamentary group of the DPRK-Poland, the Highest People's Assembly of the DPRK with the chairman Hyon Ryo Jin, also the vice-minister of energy.

In 2007 there was signed agreement about the validity of existing bilateral agreements. Among most important treaties must be mentioned agreement of cooperation in the area of fishing also about resolving the issue of DPRK's debt to Poland.

The trade exchange has reached 10,9 million Euros during the year 2007, according to the data of Economy's Ministry of (including Polish export of 0, 4 million euros). Import from DPRK was 10,5 million euros. The range of sales is small, only once - in 2005 - has exceeded the 20 million euros, since 2001 time frame.

Table 1. Value of trade Poland-DPRK

\begin{tabular}{|l|c|c|c|c|c|c|c|c|}
\hline & $\mathbf{2 0 0 2}$ & $\mathbf{2 0 0 3}$ & $\mathbf{2 0 0 4}$ & $\mathbf{2 0 0 5}$ & $\mathbf{2 0 0 6}$ & $\mathbf{2 0 0 7}$ & $\mathbf{2 0 0 8}$ & $\begin{array}{c}\mathbf{2 0 0 9} \\
\mathbf{1 0} \text { months }\end{array}$ \\
\hline Ekxport & 0.7 & 1.6 & 1.4 & 3.3 & 2.5 & 0.37 & 3.04 & 0.3 \\
\hline Import & 11.7 & 7.3 & 5.7 & 23.2 & 11.1 & 10.7 & 65.25 & 24.83 \\
\hline Trade Volume & 12.4 & 8.9 & 7.1 & 26.5 & 13.6 & 11.07 & 68.29 & 25.1 \\
\hline Saldo & -11.0 & -5.7 & -4.3 & -19.9 & -8.6 & -10.33 & -62.21 & -24.53 \\
\hline
\end{tabular}

Source: Ministry of Economy Republic of Poland, Warsaw, 2009

In 200717 companies have exported the goods to the DPRK. There were 222 importers indeed. During the first 4 months of 2008 Polish export has reached 226 thousand, and import 23 million euros.

In 2008 Polish North Korea, trade exchange has amounted 68,29 mln euro, polish export $3.04 \mathrm{mln}$ euro (growth about 827\%), and import 62,5 mln euro (growth about 610\%). Obstacle, for growth Polish export to North Korea are payment difficulties of north Korean companies. For spectators big surprise was Size Import from North Korea to Poland. In 2008 import growth was from $11 \mathrm{mln}$ euro to $68 \mathrm{mln}$ euro. This result was possible by re-exsport goods produced in Special Economic Zone in Kesong by Taiwan companies to Poland. 
The issue of DPRK's indebtedness was discussed by the experts from Finances' ministries of Poland and North Korea. The experts agreed on debt's amount in so called "clearing rubles". Polish representatives have accepted the amount of 1, 48 million USD.

This amount should be paid to the bank account of Korean-Polish Company of Maritime Brokers, for the purpose of purchasing the ship, the debt of this company to the Korean companies has been written off and Korean side has made renovation works of Polish Embassy in Pyongyang buildings, covering the costs. The payment was made partially. During the consultations in Warsaw the DPRK's side has raised new proposals on debt's issue.

Poland provides the DPRK with humanitarian aid. After the natural disaster of the flood in 2007 the aid was given in form of medicaments and dressing materials. As a part of this aid Poland has shipped small tractors for the agricultural cooperative, computers for the high school in Pyongyang and Faculty of Polish Language at the Foreign Languages University in Pyongyang, medical equipment for the hospital.

Polish artists participate in the Pyongyang's artistic festival. Recently the artists from Musical Theater in Gdynia have won silver medals, and in the year 2007 Danuta Stankiewicz has won silver medal. In the 2009 festival the group of pianists from the Academy of Frederic Chopin has participated. The Poland-DPRK Friendship Association works in Poland.

\section{CONCLUSIONS}

1. First 40 years of bilateral relations between Poland and DPRK was in Cold War reality. Close cooperation of two countries has basis in communist ideology and belonging to Soviet Union Camp. The first 20 years the relations was very close. Poland was invited to Neutral Countries Supervisory Commission to Korea by Korean Peoples Army and Chinese Military Volunteers. Western countries questioned neutral status of Poland and Czechoslovakia.

2. Polish Engagement to north Korea was very big in 50. and 60 . 
3. Chinese-Soviet ideological dispute has influenced on polish north Korean relations. The relations with North Korea was going to the Periphery of polish foreign policy.

4. Polish-North Korea relations were improved in mid 80. Kim Il Sung and Jaruzelski Party exchanged, State visit on high level.

5. Poland crossed to western Hemisphere, NATO 1999, European Union in 2004. Two countries have two diferent system of political values. Example of this conflict was expulsion of polish offices from Northern Part of JSA in Panmunjom.

6. In last twenty Years Poland DPRK relations was limited to diplomatic contacts.

7. Now relations basis is realism. Polish policy to North Korea in the Frameworks of EU goal is change by evolution character of North Korean regime. Poland support Reunification of Korea's by peaceful way and Six Party Talks on North Korea denuclearization .

Sixty years it is not many in the history of Korea that is already 5000 years. The above presented article is just small to contribution to the greater study that is now in a making. 